\title{
Learners' collocation use in writing: Do proficiency levels matter?
}

\author{
Nor Hazwani Munirah Lateh ${ }^{1 *}$, Sarimah Shamsudin², Abdul Halim Abdul Raof ${ }^{3}$, \\ Amaal Fadhlini Mohamed ${ }^{1}$, Najihah Mahmud ${ }^{1}$, Nazatul Syima Mohd Nasir ${ }^{1}$, and Nurul \\ Fatihah Hanapi ${ }^{1}$
}

\author{
${ }^{I}$ Faculty of Language Studies and Human Development, Universiti Malaysia Kelantan, \\ 16300 Bachok Kelantan, Malaysia \\ ${ }^{2}$ Language Academy, Faculty of Social Sciences and Humanities, Universiti Teknologi Malaysia, \\ 54100 Kuala Lumpur, Malaysia \\ ${ }^{3}$ Language Academy, Faculty of Social Sciences and Humanities, Universiti Teknologi Malaysia,
} 81300 Johor Bahru, Malaysia

\begin{abstract}
Knowledge of collocation is important in enabling learners to use a language fluently. When learners can demonstrate a good command of collocation use as they write, this results in greater fluency and proficiency. The present study is a case study that investigated the collocational knowledge of ESL learners across different proficiency levels. Specifically, the extent to which the learners produce lexical collocation in writing is examined in the study. To this end, a writing task (an essay) was administered to elicit the written output of the learners. The procedure involved a total of $n=120$ undergraduate ESL learners (limited, modest, and proficient learners) studying at a public university in Malaysia. The essays collected in the study were analysed and compared in terms of the lexical collocation frequencies and categories. The results first revealed that the higher proficient students wrote slightly higher lexical collocations than their counterparts. The second finding, however, indicated that there is no significant difference in the proportion of lexical collocation $(>.05)$ written by the students, regardless of their proficiency levels. Thirdly, the results demonstrated that students of higher proficiency levels were able to write their essays with slightly more lexical collocation categories in comparison to lower proficiency level learners. Nonetheless, the students did not tap into all six lexical collocation categories in their writing. The findings of the study provide insights into the lexical collocation knowledge of Malaysian ESL undergraduates across various proficiency levels.
\end{abstract}

Keywords: Collocation; collocation knowledge; English as a second language learner; writing

\begin{tabular}{|c|c|c|}
\hline $\begin{array}{l}\text { First Received: } \\
\text { 25 January } 2021 \\
\text { Final Proof Received: } \\
23 \text { September } 2021\end{array}$ & $\begin{array}{c}\text { Revised: } \\
5 \text { May } 2021\end{array}$ & $\begin{array}{c}\text { Accepted: } \\
\text { 22 July } 2021 \\
\text { Published: } \\
\text { 30 September } 2021\end{array}$ \\
\hline \multicolumn{3}{|c|}{$\begin{array}{l}\text { How to cite (in APA style): } \\
\text { Lateh, N. H. M., Shamsudin, S., Raof, A. H. A., Mohamed, A. F., Mahmud, N., Nasir, N. S. M., } \\
\text { \& Hanapi, N. F. (2021). Learners' collocation use in writing: Do proficiency levels } \\
\text { matter? Indonesian Journal of Applied Linguistics, 11(2), 418-426. } \\
\text { https://doi.org/10.17509/ijal.v11i2.31632 }\end{array}$} \\
\hline
\end{tabular}

\section{INTRODUCTION}

The basis of language learning is to acquire various components of the language especially its vocabulary. Vocabulary is an instrumental part of a language that learners should know or otherwise, they will not be able to use the language either receptively or productively. In this regard, Nation (2001) advocates that acquisition of vocabulary knowledge happens when it involves three main elements, namely word form, word meaning, and word use. In other words, to ensure a full knowledge of a word is acquired, learners are required to know

\footnotetext{
*Corresponding Author

Email: hazwani.1@umk.edu.my
} 
how it is written and pronounced, its meaning, other words which can be associated with it (collocations) (Nation, 2001). Without knowing what words are to be used together which is also known as collocation, learners are not considered to have acquired full knowledge of a certain vocabulary(Tsai, 2015).

The notion of collocation was first coined by Firth (1957) in who defined it as co-occurring words. Additionally, Henriksen (2013) explains collocation as "frequently recurring two-to-three word syntagmatic units which can include both lexical and grammatical words, e.g. verb + noun (pay tribute), adjective + noun (hot spice), preposition + noun (on guard), and adjective + preposition (immune to)".

When learning collocation, it is equally important for learners to acquire it receptively and productively (Tsai, 2015). This means learners should not only be able to comprehend or understand meanings of word combinations (collocations) found in a text but also can recall their knowledge of the collocations hence produce it on their own either in written or spoken forms (Nation, 2001).

In the contexts of writing assessment and evaluation, vocabulary is one of many salient components (e.g. grammar, spelling, idea generation) which examiners often focus on (Dunsmuir et al., 2015). In providing a score to any piece of writing written by learners, regardless of the scoring method used, examiners commonly look at how diverse and rich the vocabulary which the learners have used to express their ideas in the essays (Galti et al., 2018).

It is not surprising then to find that essays written with more diverse and sophisticated vocabulary are rated more positively hence awarded with higher scores by the examiners (Vögelin et al., 2019).

For learners, using the right combination of vocabulary or words (collocation) will make their writing more natural, accurate, and native-like. A learner who writes "please keep the secret only to yourself" would sound more accurate and fluent as compared to the one who writes "please make sure that only we know about this thing". Likewise, writing a sentence with a collocation of "the two partners are closely acquainted" brings the learner closer to a native-like writer in comparison to writing it without a collocation as in "the partners always see each other in life". In short, having good collocational knowledge will bring the learners to more advanced use of the language as they can communicate precisely and sound more native-like. This is why it becomes imperative for learners to acquire collocational competence to ensure that they can write proficiently in the language (Laufer \& Waldman, 2011).

It is undeniable that the writing process involves multiple aspects such as idea development, sentence structure, grammar, punctuation and so on that will determine the quality of a piece of writing (Dunsmuir et al., 2015). However, according to Nation (2001), it would be unlikely possible for learners to convey their messages at all if they do not have sufficient vocabulary knowledge, which entails the knowledge of collocation. This highlights the clear significance of collocational knowledge to learners' writing skills hence explains why it is important for the present study to examine the collocation knowledge of learners across different proficiency levels.

In addition to the theoretical support, various empirical studies around the globe have also revealed the importance of collocation knowledge to learners' writing performance. For example, a study conducted in Korea by Kim and Bae (2012) indicated a significant correlation between learners' collocation knowledge and their writing proficiency. The participants of the study who are Korean university students were found to be able to write high-quality essays as their collocation knowledge improves. In Iran, researchers have found that learners' writing proficiency is significantly correlated with their collocation knowledge (Yazdandoost et al., 2014). Moreover, Abdi and Ariffin (2020) in a more recent study that explores the effects of Djiboutian postgraduate students' knowledge of collocation on their writing production found a positive correlation between the collocational knowledge and writing production of the students.

Collocational knowledge can be classified into two types which are grammatical collocation and lexical collocation (Benson et al., 1997).

Grammatical collocation is a combination of main words such as noun, adjective, verb, or adverb with a preposition, infinitive, or 'that-clause. On the other hand, lexical collocation consists of lexical words which co-occur. It consists of only lexical elements and does not contain any grammatical items. The lexical words may come from nouns, adjectives, verbs, or adverbs (Benson et al., 1997). Table 1 below shows some examples of grammatical collocation and lexical collocation.

Table 1

Example of Grammatical and Lexical Collocation

\begin{tabular}{ll}
\hline \multicolumn{1}{c}{ Type } & Example \\
\hline Grammatical collocation & angry at, hungry for, afraid of \\
\hline Lexical collocation & $\begin{array}{l}\text { walk slowly, heavy rain, } \\
\text { commit a murder }\end{array}$ \\
\hline
\end{tabular}

\section{Lexical collocation category}

Focusing on lexical collocation, Benson et al. (1997) have classified it into six categories. They are verb + noun, verb + adverb, noun + verb, noun + noun, adverb + adjective as well as adjective + noun. Examples of each lexical collocation category are provided in the following Table 2 . 
Table 2

Lexical Collocation Category and Example

\begin{tabular}{ll}
\hline Category & Example \\
\hline Verb + noun /pronoun / prepositional phrase & Keep promise, do homework, come to an agreement \\
Verb + adverb & Affect deeply, amuse thoroughly, appreciate sincerely \\
Noun + verb & Alarm goes off, bees buzz, bombs explode \\
Noun +of + noun & A bouquet of flowers, a bit of advice, a colony of bees \\
Adverb + adjective & Deeply absorbed, strictly accurate, closely acquainted \\
Adjective + noun & Strong tea, best regard, extended family \\
\hline
\end{tabular}

Source: Benson et al., (1997:25-28)

As shown in Table 2 above, the six categories of lexical collocation as described by Benson et al. (1997) include the verb + noun/pronoun/prepositional phrase, verb + adverb, noun + verb, noun + noun, adverb + adjective as well as adjective + noun categories.

Past studies on learners' collocational knowledge To date, various research studies have been conducted to understand the collocational knowledge of English language learners (Abdullah et al., 2015; Chang, 2018; Dokchandra, 2019; Harida \& Hamka, 2019; Hong et al., 2011; Kamarudin et al., 2020; Mirsalari et al., 2019; Wongkhan \& Thienthong, 2020). In this regard, high attention is observed to be directed to adult learners as compared to young learners. This could be explained by the nature of adult communication which tends to use longer and complete phrases when communicating. Hence there is a higher chance and need for collocation use among adults as compared to children. A review of past studies also reveals that much effort has been geared towards investigating collocation errors committed by learners, instead of analyzing the collocation knowledge gap between learners across different proficiency levels.

In a study conducted by Chang (2018) for example, collocational errors committed by Korean adult L2 learners were examined using their writing output. The findings of the study showed the learners committed collocational errors as they are confused about synonyms, wrote incorrect word associations, and interpreted the meaning of the collocation wrongly. Interestingly, the study observed that even when they were able to write correct collocations, the learners were found to fail in using them in the right situation or context.

Furthermore, Dokchandra (2019) examined the collocational competence of 153 Thai undergraduate level students. The students were of three different academic years $\left(2^{\text {nd }}, 3^{\text {rd, }}\right.$ and $4^{\text {th }}$ year $)$ studying at a university in northeastern Thailand. To explore the students' collocational competence, the researcher administered a collocational competence test which was developed for the study. In addition to the test, the students were also required to answer a set of questionnaires that aimed to elicit their perception of the collocation difficulty. The findings showed that all students attained a moderate level of collocational competence, regardless of their academic year. In other words, the student's knowledge of collocations is not significantly different from each other even though they have a different amount of exposure to the language.

Contradicting to Dokchandra (2019), the findings of Wongkhan and Thienthong (2020)'s study revealed that learners' academic experience does affect their collocation knowledge. They examined learners' knowledge of academic collocation by administering a collocation test to two groups of 120 Thai English major undergraduate learners. The findings of the study showed that the senior students $\left(3^{\text {rd }}\right.$ and $4^{\text {th }}$ year) outperformed the juniors ( $1^{\text {st }}$ and $2^{\text {nd }}$ year) in the collocation tests administered. This suggests that indirect teaching and exposure to collocation which the learners received throughout their studies at the university somehow contributed to their acquisition of academic collocation. This study, however, only focused on the learners' knowledge of academic collocation.

Harida and Hamka (2019) also explored the collocation knowledge of undergraduate students majoring in English. The researchers had opted for a multiple-choice collocation test to gauge the students' mastery of collocations. Results revealed the students had low mastery of the collocations where the majority of them scored less than 50 percent for the test. Thus, it is concluded in the study that the students' ability to comprehend and understand English collocations was still poor, even though they were already at the university level. The abovementioned studies have all focused on the English major students in examining learners' collocation knowledge. It will also be insightful if learners of another background of study are included in exploring their knowledge of collocation.

To investigate receptive and productive collocation knowledge of Iranian EFL learners, Mirsalari et al. (2019) administered a collocation test containing multiple-choice as well as fill-in-theblank collocation questions. A total of 56 Iranian learners were involved in the study. The results revealed that the students' productive knowledge of collocation is much more limited than their receptive knowledge. However, there is no significant relationship between their receptive and productive knowledge of collocation. Moreover, the findings of the study demonstrated equal mastery of 
both types of collocation (adjective + noun $\&$ verb + noun) by the students. This study however did not take into account all the six types of collocation categories proposed by Benson et al. (1997) in analysing the students' collocation knowledge.

In the context of Malaysian ESL learners, Hong et al. (2011) were among the early researchers who undertook a study to explore learners' collocational knowledge. In specific, Hong et al. (2011) investigated collocational errors contained in the Malaysian learner corpus named EMAS (The English of Malaysian School Students). The study found that the learners produced seven types of collocational errors, with the highest occurrence of preposition-related collocational errors. It was also revealed that intralingual transfer is the main source of collocational error committed by the learners. Hong et al. (2011) focused on school students instead of undergraduates. Instead of examining the competency of the students to produce lexical collocations when writing, the objective of the study was to identify collocational errors produced by the students. Hence, the finding was not able to inform to what extent lexical collocations are produced as students of various proficiency levels are writing in the language.

In another study, Abdullah et al. (2015) investigated the collocational competence of Malaysian university students and observed its relationship with the students' overall proficiency. To this end, a lexical collocation test was administered in the study. The students were also required to take a speaking proficiency test which was adopted from the International English Language Testing System (IELTS). The study revealed no significant correlation between the students' knowledge of lexical collocation and their overall proficiency level. It is important however to note that this study only involved a small number of participants $(n=30$ students). Thus, the results are not conclusive to indicate such a relationship between learners' collocation knowledge and proficiency.

Recently, Kamarudin et al. (2020) conducted a study to investigate receptive and productive collocation knowledge of Malaysian university students. Three types of collocations (verb + noun, adjective + noun, verb + preposition) were focused on where receptive and productive collocation tests were administered. The results indicated that the students' productive collocation knowledge lags behind their receptive collocation knowledge. Moreover, the findings observed that the students had higher difficulty in comprehending as well as producing the verb + preposition collocation as compared to the other two collocation types (verb + noun, adjective + noun). Despite its findings, only a small number of students took part in the study ( $n=21$ students), which is why the results are not generalisable to other populations of Malaysian ESL learners. Furthermore, only intermediate level students were involved hence the findings are not strong enough to shed light on collocation knowledge of Malaysian ESL learners across various proficiency levels.

Although there is a growing number of research studies investigating collocation knowledge of ESL learners, there are however few studies that take into account learners across various proficiency levels, in which it is very important for their collocation knowledge to be identified for them to achieve greater fluency in the language (Boers et al., 2013).

It is clear from the abovementioned studies that existing research on collocation knowledge of Malaysian ESL learners still lacks comprehensive investigation of how learners across various proficiency levels tap into their collocation knowledge hence produce lexical collocation when writing in the language. To address this, the present study aims to explore the collocation knowledge of Malaysian ESL undergraduate learners who are at three different proficiency levels namely limited, modest and proficient. The objective of the study was achieved by answering the following research questions.

1. To what extent do limited, modest, and proficient learners produce lexical collocation in writing?

2. Do the limited, modest, and proficient learners produce significantly different lexical collocations in writing?

3. What type of lexical collocation categories are written by limited, modest, and proficient learners?

\section{METHOD}

The present study is a case study that aims to investigate in depth the extent to which Malaysian ESL undergraduates who are at different proficiency levels can produce lexical collocation as they are writing in the language. As for the research method, the study applies the quantitative research method in its data analysis procedure. In this regard, a frequency analysis was undertaken to count the frequency of lexical collocation which the students produced in their writings. In addition, frequency analysis was carried out to measure the extent of the lexical collocation category written by the students. Furthermore, descriptive analysis followed by statistical analysis (one-way ANOVA test) was performed to assess whether there was a significant difference in terms of lexical collocations produced by the students.

\section{Participants}

A total of $n=120$ first-year students from a public university in Malaysia took part in this study. Their ages were between 19 to 22 years old. The reason why the first-year students were targeted was due to 
the need of identifying their current vocabulary knowledge which includes collocation knowledge so that necessary steps could be taken to improve their knowledge throughout their upcoming years at the university. The students' proficiency level was first determined by their Malaysian University English Test (MUET) results.

MUET is a national English proficiency test that gauges all the four skills of learners (reading, writing, listening, and speaking). Students who wish to pursue tertiary education in Malaysian public universities must first sit for MUET to ascertain their English proficiency levels. The MUET result is presented in six bands corresponding to six proficiency levels. They are Band 1 (very limited), Band 2 (limited), Band 3 (modest), Band 4 (satisfactory), Band 5 (proficient), and Band 6 (highly proficient).

In the present study, 50 students of Band 2 (limited), 45 students of Band 3(modest), and 25 students of Band 5 (proficient) were involved. The students were chosen based on their convenience and availability to take part in the study.

\section{Research instrument}

To find answers to the research questions, a descriptive writing task had been developed and administered in the study. The descriptive writing task was intended to elicit the written production of the students which later was compiled as the Corpus of Malaysian Learner Written English (CORMALWE).

In order to ensure that the writing task was not cognitively challenging to the students, the researcher had adapted its format and topic from a past year MUET question. By using a task which they are familiar with, it is hoped it would increase the students' motivation to write their essays better hence producing richer data for the study. Details of the writing task are described in Table 3 below.

The students were asked to attend a session to write their essays. The data collection process was done by the researcher herself along with the help from their lecturers. The students were required to write their essays in a handwritten format to avoid any plagiarism issues.

Table 3

Details of the Descriptive Writing Task

\begin{tabular}{lc}
\hline Topic & Length \\
\hline $\begin{array}{l}\text { Describe how online social applications such as Facebook, WeChat, and Whatsapp } \\
\text { can benefit your study. }\end{array}$ & Minimum \\
\hline
\end{tabular}

A total of 120 essays were collected in the study. The essays were then converted into a Microsoft Word file and compiled as the CORMALWE. Altogether, the CORMALWE consists of 49680 tokens. The CORMALWE was also separated into three subcorpus to differentiate between the corpus of limited, modest, and proficient level students. For analysis purposes, it is necessary for the token size of the subcorpus to not differ significantly from each other. This is to ensure a fair comparison can be made between lexical collocation produced in the corpora (Koizumi, 2012; Nation \& Webb, 2011).

The subcorpus consists of the following tokens as shown in Table 4.

Table 4

Token Size for the Subcorpus

\begin{tabular}{ll}
\hline Sub corpus & Token size \\
\hline Limited & 16780 \\
Modest & 16530 \\
Proficient & 16370 \\
\hline
\end{tabular}

\section{Data analysis}

The individual subcorpus had been analysed for lexical collocation use. A manual analysis was done to check and count the frequency of lexical collocation contained in the respective corpus. The lexical collocation counted in the study should be spelled correctly with no grammatical errors done as that is necessary for them to be considered having acquired the collocation knowledge (Nation, 2001). Furthermore, the analysis does not consider repeated lexical collocation written by the same student.

To verify the lexical collocations analysed in the corpus, the British National Corpus (BNC), as well as the Oxford Collocations Dictionary, were referred. Collocations that were written should be listed in both references to be counted. Furthermore, second opinion was sought from two English lecturers who have had more than five years of teaching experience.

\section{FINDINGS AND DISCUSSION}

The first research question of the study is to find out the extent to which the limited, modest and proficient students are able to produce lexical collocation as they are writing in the language. To this end, the frequency of lexical collocation occurrence in the students' corpus had been examined, with reference to the British National Corpus (BNC) and the Oxford Collocations Dictionary. Table 5 illustrates descriptive statistics of lexical collocations written in the corpus.

As shown in Table 5, the limited level students wrote the lowest number of lexical collocations in their essays (average $=8$ lexical collocations) followed by the modest (average $=9$ lexical collocations) and the proficient learners (average $=10$ lexical collocations). 
Table 5

\begin{tabular}{llll}
\multicolumn{2}{c}{ Descriptive Statistics } & of Lexical & Collocation \\
\hline & $\begin{array}{l}\text { Limited } \\
(\mathbf{1 6 7 8 0} \\
\text { tokens) }\end{array}$ & $\begin{array}{l}\text { Modest } \\
(\mathbf{1 6 5 3 0} \\
\text { tokens) }\end{array}$ & $\begin{array}{l}\text { Proficient } \\
(\mathbf{1 6 3 7 0} \\
\text { tokens) }\end{array}$ \\
\hline Mean & 8 & 9 & 10 \\
Median & 8 & 8 & 10 \\
SD & 2 & 4 & 2 \\
Min & 3 & 4 & 8 \\
Max & 12 & 15 & 13 \\
\hline
\end{tabular}

The results suggest that lexical collocations produced by the higher proficient students are just slightly higher than their counterparts. To confirm whether the difference is significant or not and hence providing answers to the second research question of the study (Do the limited, modest and proficient learners produce significantly different lexical collocations in writing?), a one-way ANOVA test was carried out.
Accordingly, the one-way ANOVA test reveals no significant difference between lexical collocations written by the students ( $p>.05)$. This indicates the lexical collocations written by the students were not significantly different from each other. This result suggests that the ability of the limited, modest, and proficient learners to use lexical collocation in their writing is pretty much the same, despite the discrepancy in their overall proficiency levels.

The answer to the third research question (What type of lexical collocation categories are written by the limited, modest, and proficient learners) was obtained from analysing all the lexical collocations found in their respective corpus. In relation to this, the six lexical collocation categories by Benson et al. (1997) were referred to. The findings are described in Table 6.

Table 6

Result of Lexical Collocation Category

\begin{tabular}{lccc}
\hline Collocation Category & $\begin{array}{c}\text { Limited } \\
(\mathbf{1 6 7 8 0} \text { tokens })\end{array}$ & $\begin{array}{c}\text { Modest } \\
\text { (16530 tokens) }\end{array}$ & $\begin{array}{c}\text { Proficient } \\
(\mathbf{1 6 3 7 0} \text { tokens) }\end{array}$ \\
\hline Verb + Noun/pronoun/prepositional phrase & 75 & 75 & 76 \\
Adjective + Noun & 40 & 56 & 69 \\
Noun + Verb & 0 & 0 & 0 \\
Noun + of + Noun & 0 & 0 & 0 \\
Adverb + Adjective & 0 & 1 & 4 \\
Verb + Adverb & 0 & 2 & 2 \\
Total & 115 & 134 & 151 \\
\hline
\end{tabular}

It can be seen from Table 6 that the limited level students wrote the fewest proportion (115 lexical collocations) and category (2 categories) of lexical collocation when writing the essays. Specifically, the students wrote 75 lexical collocations which are from the verb + noun/pronoun/prepositional phrase category while 40 of them are from the adjective + noun category. Some examples of lexical collocations which the students wrote were 'answer calls', 'ask a question', 'learning process', 'provide information' and 'solve problem'.

As for the modest level students, the results indicate that they wrote four lexical collocation categories in the essays. The total number of lexical collocations written by this group of students is 134 . Most of them come from the verb + noun/pronoun/ prepositional phrase category (75 lexical collocations), followed by the adjective + noun category (56 lexical collocations), verb + adverb category (2 lexical collocations) and lastly adverb + adjective category (1 lexical collocation). Some examples of lexical collocations written by the modest level students include 'commit suicide', 'enhance knowledge', 'personal information', 'phone calls' and 'take a break'.

Interestingly, the proficient level students also tapped into the same four categories of lexical collocations in writing their essays. They are the verb + noun/pronoun/prepositional phrase category (76 lexical collocations), adjective + noun category (69 lexical collocations), adverb + adjective category (4 lexical collocations) as well as the verb + adverb category ( 2 lexical collocations). The total number of lexical collocations found in the essays of the proficient level students is 151. A few examples of lexical collocations written by the proficient level students include 'acquire knowledge', 'attend a meeting', 'general knowledge', 'immensely popular', and 'obtain information'.

The present study attempts to explore the lexical collocation knowledge of Malaysian undergraduate students who are at different proficiency levels (limited, modest, and proficient). In this regard, the proportion of lexical collocation of various categories written by the students was explored in the study. Thus, the findings of the study provide useful insights into the lexical collocation knowledge gap among ESL undergraduate learners across various proficiency levels.

Through analysing the writing output of the students, three interesting findings are unveiled in the study. These findings provide useful insights into the lexical collocation competence of Malaysian ESL undergraduates across various proficiency levels. First, the students were found to produce about the same proportion of lexical collocations as they write in the language. In other 
words, there was no difference between the lexical collocations that the students produced in writing even though they were of different proficiency levels. This finding is in line with Abdullah et al. (2015) study as they found no significant correlation between university students' knowledge of lexical collocation and their overall proficiency level.

One possible reason to explain the abovementioned finding is that the students might have learned and acquired the vocabulary of the language individually. This always happens among English language learners as asserted by Nation (2001) when they acquire words individually. However, this leads the students to miss out on word associations and their context and hence fail to effectively employ lexical collocation as they are functioning in the language (Nation, 2001). Therefore, it is of no surprise why the students could write the essays with loads of vocabulary, and yet no significant use of lexical collocation was found in their writing.

It is also important to note that the nature of the writing task could have also influenced such results to be obtained. As explained, the students were given only one hour to complete the writing task, and the word limit set for the writing task was also not too long (350 words) for more lexical collocations to be written by the students. In sum, the topic, as well as the context of the writing task, might have not given the students enough opportunity to tap into their lexical collocation knowledge hence produce it in their writing

The second major finding of the study indicates that the students of higher proficiency levels were able to tap into more of the lexical collocation categories as compared to their counterparts. Despite the proportion of lexical collocations which all the students wrote was not significantly different, the pattern of their lexical collocation use was somehow different. With reference to that, the limited level students were only able to utilize two types of lexical collocation categories to write their essays. On the contrary, the modest and proficient level students managed to tap into four lexical collocation categories when writing essays of the same topic. This finding is quite interesting as it shows the gap and variation in the students' ability to produce the different types of lexical collocation categories as they are writing in the language.

Thirdly, the finding of the study indicates the students did not employ all the six lexical collocation categories as proposed by Benson et al., (1997). Specifically, only four of the categories were written by the students namely, the verb + noun/pronoun/prepositional phrase, adjective + noun, adverb + adjective as well as the verb + adverb categories.

In relation to the underuse of lexical collocation category written by the students, one possible explanation for this might be the lexical collocation categories which were not employed or written by students could be of higher difficulty level for them. The lexical collocation categories could have exerted more difficulty to the students in doing so. This may clarify why they resorted to employing only four out of six lexical collocation categories in their writings.

As explained, collocation is one part of vocabulary knowledge and it is often not given much attention by learners. It is generally understood that learners would learn and acquire individual words first before they progress to learning the collocations. However, research studies constantly have reported that Malaysian university students are weak in terms of their vocabulary knowledge (Lateh et al., 2018, 2019; AbManan et al., 2017). The predicament in vocabulary knowledge is especially evident in the lowproficient students. From this insight, we can infer that the poor lexical collocation performance of the students may result from the students' poor vocabulary knowledge.

As mentioned, Malaysian ESL students are familiar with learning words individually rather than in context. There is also no specific focus given on collocation teaching in the English language syllabus. Thus, it is of no surprise that the students, even the proficient level students, were unable to demonstrate significant understanding and use of lexical collocation.

As lexical collocation use is evidently important to fluency and accuracy of learners' language use (Boers et al., 2013), what has been shown by the current findings is quite alarming. Essentially, the findings inform the difficulty faced by the Malaysian ESL undergraduates in using lexical collocations when they are writing in the language. Although some of the students were proficient users of the language, this however does not reflect in their use of lexical collocations.

The findings obtained in the study implicate the need for effective collocation teaching to be carried out at the university. This can be done along with other important vocabulary elements that are deemed important for tertiary-level learners to know which include among others the academic vocabulary, and general service vocabulary.

Collocation teaching can be performed in various interesting ways. One of them is by employing the Mobile-Assisted Language Learning (MALL) method. Mobile applications such as Whatsapp have been proven as an effective way to teach collocation to learners (Ashiyan \& Salehi, 2017). Furthermore, research studies have found social media applications such as Whatsapp as an interactive medium to boost collocation learning among learners (Arifani, 2019). More importantly, such mobile-assisted language learning is highly recommended by learners themselves due to its 
usefulness in and outside of the classroom (Alhadiah, 2020).

Another platform that teachers and learners can utilise to access collocation is the concordance software such as MonoConc and WordSmith Tools. Direct reference to the corpus is also an effective way to teach collocation to learners (Li, 2017; Reynolds, 2016). When corpus is utilised, it is easier for learners to see real examples of collocation use in writing and speaking. Teaching of collocations through communicative teaching methods where learners are given the opportunity to request, check, repeat and consult on their comprehension of collocations learned is also found to be useful in improving learners' collocation knowledge (Suphon, 2019).

\section{CONCLUSION}

The present study has put forward findings of poor collocation use in writing among Malaysian ESL university students across different proficiency levels. Proactive steps, are, therefore, necessary to be taken to promote more effective collocation teachings to the students.

Despite all the findings obtained, there are a few limitations of the present study which are worth mentioning. Firstly, the participants of the study came from only one public university in Malaysia. Currently, there are 20 public universities in Malaysia in which researchers can go to get richer data of lexical collocation competence of Malaysian ESL undergraduates. Secondly, the data analysed in the study were obtained through a descriptive writing task that had been developed for the study. The findings might change if another type of writing task on another topic was employed in the study. Hence, a larger-scale study, involving students from other universities and collocation production tests is deemed to be carried out to gain more comprehensive insights on the lexical collocational competence of Malaysian ESL undergraduate students across various proficiency levels.

\section{REFERENCES}

Abdi, B. M., \& Ariffin, A. (2020). The relationship between collocation competence and writing skills of EFL learners. The Asian Journal of English Language \& Pedagogy, 8(1), 41-52.

Abdullah, A., Abdul Ghani, R., \& See, S. Y. (2015). The knowledge of lexical collocation among university students and its relation to their speaking proficiency. International Letters of Social and Humanistic Sciences, 61, 7-16. https://doi.org/10.18052/www.scipress.com/ils hs. 61.7

AbManan, N. A., Azizan, N., \& Mohd Nasir, N. F. W. (2017). Receptive and productive vocabulary level of diploma students from a public university in Malaysia. Journal of Applied Environment and Biological Sciences, 7(1S), 53-59.

Alhadiah, A. (2020). EFL learners ' experience of a MALL-based vocabulary learning tool. Indonesian Journal of Applied Linguistics, 10(2), 283-291. https://doi.org/10.17509/ijal.v10i2.28590

Arifani, Y. (2019). The application of small WhatsApp groups and the individual flipped instruction model to boost EFL learners' mastery of collocation. CALL-EJ, 20(1), 5273.

Ashiyan, Z., \& Salehi, H. (2017). A comparison of male and female learners' English collocation learning through using WhatsApp. International Journal of Research Studies in Educational Technology, 6(1), 25-42. https://doi.org/10.5861/ijrset.2016.1615

Benson, M., Benson, E., \& Ilson, R. F. (1997). The BBI combinatory dictionary of English: A guide to word combinations (2nd ed). John Benjamins Publishing.

Boers, F., Demecheleer, M., Coxhead, A., \& Webb, S. (2013). Gauging the effects of exercises on verb-noun collocations. Language Teaching Research, 18(1), 54-74. https://doi.org/10.1177/1362168813505389

Chang, Y. (2018). Features of lexical collocations in L2 writing: A case of Korean adult learners of English. English Teaching, 73(2), 3-36. https://doi.org/10.15858/engtea.73.2.201806.3

Dokchandra, D. (2019). Thai EFL learners' collocational competence and their perceptions of collocational difficulty. Theory and Practice in Language Studies, 9(7), 776-784. https://doi.org/10.17507/tpls.0907.04

Dunsmuir, S., Kyriacou, M., Batuwitage, S., Hinson, E., Ingram, V., \& O’Sullivan, S. (2015). An evaluation of the Writing Assessment Measure (WAM) for children's narrative writing. Assessing Writing, 23, 1-18. https://doi.org/10.1016/j.asw.2014.08.001

Firth, J. R. (1957). Papers in Linguistics, 19341951. Oxford University Press.

Galti, A. M., Saidu, S., Yusuf, H., \& Goni, A. A. (2018). Rating scale in writing assessment: Holistic vs. Analytical scales: A review. Internatioal Journal of English Research, 4(6), 4-6.

Harida, E. S., \& Hamka, H. (2019). Collocations mastery of the university students. Journal of English Linguistics, Literature and Education, 1(2), 201-208.

Henriksen, B. (2013). Research on L2 learners' collocational competence and development: A progress report. In C. Bardel, C. Lindquist, \& B. Laufer (Eds.), L2 vocabulary acquisition, knowledge and use: New perspectives on assessment and corpus analysis (pp. 29-56). 
Eurosla.

Hong, A. L., Rahim, H. A., Hua, T. K., \& Salehuddin, K. (2011). Collocations in Malaysian English learners' writing: A corpusbased error analysis. 3L: Language, Linguistics, Literature, 17(Special Issue), 3144.

Kamarudin, R., Abdullah, S., \& Abdul Aziz, R. (2020). Examining ESL learners' knowledge of collocations. International Journal of Applied Linguistics and English Literature, 9(1), 1-6. https://doi.org/10.7575/aiac.ijalel.v.9n.1p.1

Kim, H., \& Bae, J. (2012). The relationship of collocation competence with reading and writing skills. English Teaching, 6(3), 95-119. https://doi.org/10.15858/engtea.67.3.201209.9 5

Koizumi, R. (2012). Relationship between text length and lexical diversity measures: Can we use short texts of less than 100 tokens? Vocabulary Learning and Instruction, 1(1), 60-69.

https://doi.org/10.7820/vli.v01.1.koizumi

Lateh, N. H. M., Shamsudin, S., \& Abdul Raof, A.

H. (2018). Receptive vocabulary levels of Malaysian university students. LSP International Journal, 5(1), 105-113. https://doi.org/10.11113/lspi.v5n1.68

Lateh, N. H. M., Shamsudin, S., \& Raof, A. H. A. (2019). English language receptive vocabulary profile: A case of novice business undergraduate students. Journal of Nusantara Studies (JONUS), 4(2), 29-44. https://doi.org/10.24200/jonus.vol4iss2pp2944

Laufer, B., \& Waldman, T. (2011). Verb-noun collocations in second language writing: A corpus analysis of learners' English. Language Learning: A Journal of Research in Language Studies, 61(2), 647-672.

https://doi.org/10.1111/j.14679922.2010.00621.x

Li, S. (2017). Using corpora to develop learners' collocational competence. Language Learning and Technology, 21(3), 153-171. https://doi.org/10125/44625

Mirsalari, S. A., Bazvand, A. D., \& Khoram, A. (2019). An investigation into the developmental patterns of lexical collocation among Iranian EFL learners. Applied Linguistics Research Journal, 3(2), 48-69. https://doi.org/10.14744/alrj.2019.02486

Nation, P. (2001). Learning vocabulary in another language. Cambridge University Press.

Nation, P., \& Webb, S. (2011). Researching and analyzing vocabulary. Heinle.

Suphon, C. S. F. A. C. (2019). The effectiveness of form focused instruction in augmenting the use of verb noun collocations in L2 learners' writing [Unpublished master thesis]. University of Malaya.

Reynolds, B. L. (2016). Action research: Applying a bilingual parallel corpus collocational concordancer to Taiwanese medical school EFL academic writing. RELC Journal, 47(2), 213-227. https://doi.org/10.1177/0033688215619518

Tsai, K. J. (2015). Profiling the collocation use in ELT textbooks and learner writing. Language Teaching Research, 19(6), 723-740. https://doi.org/10.1177/1362168814559801

Vögelin, C., Jansen, T., Keller, S. D., Machts, N., \& Möller, J. (2019). The influence of lexical features on teacher judgements of ESL argumentative essays. Assessing Writing, 39(2019), 50-63. https://doi.org/10.1016/j.asw.2018.12.003

Wongkhan, P., \& Thienthong, A. (2020). EFL learners' acquisition of academic collocation and synonymy: Does their academic experience matter? RELC Journal, 1-16. https://doi.org/10.1177/0033688219895046

Yazdandoost, Z., Amalsaleh, E., \& Kafipour, R. (2014). The relationship among collocation knowledge and listening, speaking, reading and writing proficiency of Iranian EFL learners. Journal of International Scientific Publications, 8, 408-419. 